\title{
Takeover Threats and Managerial Myopia
}

\section{Citation}

Stein, Jeremy C. 1988. Takeover threats and managerial myopia. Journal of Political Economy 96(1): 61-80.

\section{Published Version}

http://dx.doi.org/10.1086/261524

\section{Permanent link}

http://nrs.harvard.edu/urn-3:HUL.InstRepos:3708937

\section{Terms of Use}

This article was downloaded from Harvard University's DASH repository, and is made available under the terms and conditions applicable to Other Posted Material, as set forth at http:// nrs.harvard.edu/urn-3:HUL.InstRepos:dash.current.terms-of-use\#LAA

\section{Share Your Story}

The Harvard community has made this article openly available.

Please share how this access benefits you. Submit a story.

\section{Accessibility}




\section{Takeover Threats and Managerial Myopia}

\section{Jeremy C. Stein}

Harvard University

This paper examines the familiar argument that takeover pressure can be damaging because it leads managers to sacrifice long-term interests in order to boost current profits. If stockholders are imperfectly informed, temporarily low earnings may cause the stock to become undervalued, increasing the likelihood of a takeover at an unfavorable price; hence the managerial concern with current bottom line. The magnitude of the problem depends on a variety of factors, including the attitudes and beliefs of shareholders, the extent to which corporate raiders have inside information, and the degree to which managers are concerned with retaining control of their firms.

\section{Introduction}

The current wave of corporate takeovers has intensified the debate over their social desirability. On one side of the fence stand the raiders, along with many economic and legal scholars, arguing that takeovers serve two important functions: First, they allow acquiring firms to generate economies of scale or scope, apply superior knowledge or skills, or otherwise create a value-improving synergy. Second, the very threat of takeover disciplines entrenched management, serving them notice that they are liable to be ousted if they do not act in the best interests of their shareholders (see, e.g., Grossman and Hart 1980; Easterbrook and Fischel 1981; Scharfstein 1985).

Those less enthusiastic about takeovers have raised a number of

I am grateful to the National Science Foundation for financial support and to David Scharfstein, Oliver Hart, Jean Tirole, Bob Gibbons, Andrei Shleifer, Sam Peltzman, and seminar participants at MIT, Princeton, and Harvard for helpful comments and suggestions. 
counterpoints. One line of objection to unfettered takeover activity that has received a good deal of attention is the "managerial myopia" argument. It contends that takeover pressure, and the accompanying fear of being bought out at an undervalued price, leads managers to focus more heavily on short-term profits rather than on long-term objectives. Kuttner (1986, p. 17) makes the point as follows: "Beyond the problem of excessive borrowing, one also must consider what the casino mentality does to the entire corporate culture. In a world where whole corporations are prey, the manager who plans for the long term is a sucker... Takeover fears only intensify the obsession with the quarterly bottom line. For when reported profits drop, the stock may become undervalued, making it an easier target." In a similar vein, Auletta (1986, p. 238) remarks: "In such a climate [when takeovers are prevalent] companies often find their attention diverted to short term, defensive stances ... peddling assets [and] reducing long term capital investments in order to stretch fourth quarter earnings."

The goal of this paper is to develop a formal model of the phenomenon of managerial myopia described above. In so doing, it is hoped that some light will be shed on the following questions: (1) Can managerial myopia be consistent with rationality on the part of shareholders? How can anything that is not in the best long-run interests of the firm be used to increase the stock price? (2) How bad a problem is managerial myopia? In particular, are its negative effects ever strong enough to fully offset the positive synergy benefits associated with takeovers so that it might be socially desirable to ban takeover activity? (3) Are takeover threats the sole cause of managerial myopia? Or is the often impatient behavior of some stockholders (e.g., portfolio managers who may dump a company's stock as soon as its earnings reports are not quite up to par) also partly responsible? (4) In what way does managerial self-interest enter the problem? (5) How are the answers to these questions affected by the assumptions concerning how well informed corporate raiders are? Do raiders with "inside information" necessarily make matters worse?

In order to answer question 1 in the affirmative, one would have to appeal to some sort of informational asymmetry. If stockholders observe everything that managers do, any policy that management knows is not in the best long-run interests of the firm would lower the stock price. If, on the other hand, stockholders cannot observe all the inner workings of the firm and must rely on some imperfect summary statistic such as reported earnings, there is room for the type of costly signaling described by Spence (1973). Managers might, for example, be able to boost the stock price by selling off productive assets whose value shareholders are unable to gauge properly. If left unsold, the 
assets may have little effect on current earnings and may be undervalued by shareholders. Consequently, their sale, which has an immediate impact on the bottom line, may cause an upward revaluation of the company's stock.

In the absence of short-term pressures, there is no strong motivation for managers to devote resources to making sure that their stock is never undervalued. After all, the productive assets mentioned in the example above will eventually start to yield earnings so that the undervaluation will be transient. The signaling behavior described above becomes important when there is a chance that raiders will exploit temporary mispricings of the stock and buy the company at a price that managers consider to be unfairly low. In such cases, managers who boost their stock prices by inflating earnings may be attempting to act in the interests of stockholders by preventing them from being unfairly "ripped off" by raiders. However, as will become clear shortly, such attempts are often misguided, resulting in ex ante losses to shareholders, who could possibly be made better off by binding managers to never "interfering" with the stock price. (Of course, stock price boosting may also be undertaken by managers who have no intention of helping shareholders, but who just want to discourage takeovers so they can keep their jobs.)

Although takeover threats provide an important motivation for managerial myopia, they need not be a sole determinant. If one believes that managers attempt to pump up current earnings so as to avoid takeovers at undervalued prices, one must look not only at the extent of takeover pressure but also at the factors that may cause stocks to be undervalued in the first place. Here the behavior and beliefs of stockholders come into play. Relatively patient stockholders may not be discouraged by a low earnings report; they may attribute it to a policy of long-term investment by the firm. If patient shareholders are the norm, low earnings will not lead to a large undervaluation of the stock, and managers will not need to be overly concerned. Impatient shareholders, on the other hand, may become very distressed by low earnings reports and may try to dump a stock as soon as such a report is issued. If such impatience is widespread, managers will be more fearful of undervaluation and the accompanying possibility of rip-off by a raider. Hence efforts to boost current earnings will be more intense.

Given the preceding discussion, one would be tempted to conclude that raiders who are better informed than the average shareholder

\footnotetext{
${ }^{1}$ In this context, the problem of managerial myopia can be seen as a symptom of an imperfect contract between shareholders and managers. Ideally, shareholders might hope to write a contract that binds managers to never signaling. However, this is likely to be impossible in practice, as is explained in n. 6 .
} 
must cause more problems than raiders who are not. Well-informed raiders are more likely to pounce on an undervalued stock, which should tend to make managers more defensive in the face of such raiders. Although there is some truth to this notion (particularly when manager and shareholder interests do not coincide), it does not apply under all circumstances. As will be seen shortly, betterinformed raiders can often lead to more optimistic outcomes than lesser-informed ones.

The paper is organized as follows: Section II presents the basic model, and Section III examines the equilibria that result when raiders are "uninformed." Section IV briefly considers the case of "informed raiders." Finally, Section V discusses some of the policy and empirical implications that emerge from the analysis.

\section{The Model}

The model has three periods. At time 1, the managers of the Acme Oil Company learn how much oil their exploration activities have uncovered. In the good state, which occurs with probability $p$, they have $x_{1}$ barrels, and in the bad state, which occurs with probability $1-p$, they have $x_{2}$ barrels, with $x_{2}<x_{1}$. Shareholders do not observe which state prevails and must use the ex ante probabilities $p$ and $1-p$ in valuing the firm.

The managers can either sell oil today or wait until time 3 . Oil is a "long-term" asset, in the following sense: While the market price will remain constant over time, Acme is in the midst of developing a technology that will allow it to refine the oil more cheaply (which must be done before it can be sold). This technology will not be ready until time 3. Thus while the profit from selling oil today is $\$ 1$ per barrel, the profit from waiting until date 3 is $\$(1+r)$ per barrel. Since the real interest rate is taken to be zero, waiting is the long-run profitmaximizing strategy. ${ }^{2}$ Managers may attempt to signal the state, however, by selling today in order to boost current earnings. ${ }^{3}$ It is assumed that selling oil is the only feasible way to generate such earnings; any other methods involve prohibitive costs. ${ }^{4}$

The model rules out methods of signaling other than through current earnings. This is not meant to imply that such signals (e.g., debt-

\footnotetext{
${ }^{2}$ The "long-term" asset formulation used here is very similar to that employed in a different context by Diamond and Dybvig (1983).

${ }^{3}$ These earnings are retained by the firm until date 3 . In this model, there is no scope for the type of dividend signaling described by Bhattacharya (1979).

${ }^{4}$ This assumption is used only to make the exposition more transparent and need not be so strong. Similar results would be obtained if the marginal cost of generating current earnings above $x_{2}$ were just required to be greater for the bad-state firm.
} 
financed stock repurchases) are never used, only that they too are costly, so that signaling through earnings is relevant at the margin. ${ }^{5}$ The model also ignores ex ante contractual solutions to the problem. One interesting possibility, which will be discussed later in the paper, is that the firm adopt in its charter a "supermajority" provision or other type of antitakeover amendment that gives management greater power to block unwanted takeover bids. ${ }^{6}$

The motivation for signaling is the presence of a raider, who investigates the firm at date 2 . In the course of his investigation, the raider will turn up a synergistic improvement $v$ drawn from a probability distribution with cumulative distribution $F(v)$; that is, the date 3 profits of the firm will be augmented by an amount $v$ if the raider takes control of the firm. The raider may also learn how many barrels of oil the firm has. This will be referred to as the "informed raider" case. If he does not know which state prevails and must use the same $p$ and $1-p$ probability assessments as the stockholders, this is known as the "uninformed raider" case. In both cases, it is assumed that once the raider investigates the firm, he has the option of attempting a takeover, at a cost $c$. The cost $c$ can be thought of as representing the administrative and legal expenses incurred in making a bid. For expository purposes, $c$ will be used as a parameter that measures the degree of takeover pressure. Implicit in the discussion is the notion that such pressure can, to a degree, be controlled by policymakers: by erecting regulatory obstacles, they can effectively raise takeover costs in the form of lawsuits, increased costs of financing, and so forth.

\footnotetext{
${ }^{5}$ The editor has suggested another signaling mechanism. Managers of good-state firms could announce that they were giving up their current wages in exchange for more stock in the firm, paying a higher effective price than they would be willing to pay if the firm were bad. However, such a scheme requires that a great deal of information be verifiable by outsiders. The more stock a bad-state manager initially owns, the higher effective price he will pay for a few more shares if that payment enables him to boost the price of all his existing holdings before a takeover. Thus in order for this type of signaling to work, outsiders need to know a manager's initial holdings. This is further complicated by the fact that a manager who cares about other shareholders will behave as if he owned more shares than he actually does. These difficulties do not arise with signaling mechanisms in which the manager transacts for the firm's account rather than his own (i.e., boosting earnings, stock repurchases) since, in such cases, the costs and benefits accrue to the same "base" (all the firm's equity) and a manager's share in the base is irrelevant.

${ }^{6}$ Another contractual possibility is binding managers to never signaling through the imposition of a fine when any profits are observed at date 1. Although this is not illogical in the current model, it does seem unrealistic to penalize managers for profits of any sort. In fact, it is possible to construct a more complex model in which such unnatural fines are ruled out endogenously. This can be done by assuming that, in addition to oil, managers sometimes uncover a perishable commodity that must be sold for a profit at date 1 or totally wasted. If this occurs relatively frequently, it will not be desirable to penalize managers for date 1 profits. They must be given some discretion with respect to generating earnings.
} 
For most of what follows, it will be assumed that there is no conflict of interest between managers and current shareholders: managers own stock in the company and seek only to maximize their return from this stock. In this case, the only differences between managers and other shareholders are that managers have better information about how the company is doing, and they have discretion as to how to handle the company's assets. A few brief remarks will also be made, however, about the case in which managers enjoy control of the firm for its own sake, so that their interests are out of line with those of the other stockholders.

The model makes it clear why managers may choose to engage in signaling at date 1 . If stockholders have no information at this time, their best guess of the value of the firm is

$$
V_{0}=(1+r)\left[p x_{1}+(1-p) x_{2}\right] .
$$

But suppose that managers know that the firm is in the good state. Then from their point of view, the stock is underpriced, and it is possible that a raider may be able to rip them off by acquiring all the stock for less than its true value of $x_{1}(1+r)$. Although selling oil at date 1 is wasteful relative to waiting until date 3 , managers of a goodstate firm may be willing to do it if it can cause an upward revaluation in the firm's stock, thereby forcing any raider to pay a fair price for the firm.

The managers' decision whether or not to sell some oil at date 1 depends on several factors: how much they have to sell to change their market valuation, how large a revaluation they can produce, and how likely a raid is at date 2 .

The basic idea running through the entire analysis is this. Facilitating takeovers (as parameterized by lowering the cost of takeovers $c$ ) has two conflicting effects on social welfare: it increases the number of synergistic mergers that are consummated, but it also leads to increased wasteful signaling, in both firms that are eventually taken over and those that are not. Consequently, welfare does not improve monotonically with decreases in $c$; after a point, the negatives can begin to outweigh the positives. This nonmonotonicity result runs counter to the spirit of Grossman and Hart (1980), Easterbrook and Fischel (1981), Scharfstein (1985), and many others and suggests that allowing complete freedom in the market for corporate control may not be an optimal policy.

This notion would be much reinforced if one could also make the stronger claim that the existence of takeovers can be ex ante welfare reducing, that is, that social welfare is sometimes lower for a finite $c$ than it is when $c$ is infinite and takeovers are impossible. As it turns out, such a claim can indeed be supported, although not with com- 
plete generality. There is a noteworthy exception, a case in which one can prove that any finite $c$ leads to higher welfare than an infinite $c$. In this case, absolute abolition of takeovers would be worse than any other option.

In order to simplify the analysis, the following strong assumption is made: A raider can always buy the firm at a price that is exactly equal to what shareholders perceive to be the current worth of the company, in the absence of any improvement $v$. In the context of the dilution concept advanced by Grossman and Hart (1980), this corresponds to assuming that raiders are able to dilute the minority shares of an acquired target quite substantially and thereby capture all the surplus generated by their improvements. Although this assumption is not very realistic, it does not produce results that differ markedly from the more general case in which raiders capture only a portion of the surplus they generate.

\section{The Case of Uninformed Raiders}

The first case to be studied is that in which the raiders, like the shareholders, do not know which state of the world prevails until time 3 . Since raiders and stockholders are symmetrically informed, the stock price will always be a "fair" one to any raider, whether or not managers engage in signaling. That is, the stock price (assuming riskneutral shareholders) will always equal a raider's expectation of the current worth of the firm. Consequently, a risk-neutral raider who is able to capture the entire surplus created by his improvement $v$ will make a takeover bid if $v \geq c$. So at date 1 , a manager assesses the probability of takeover at date 2 as $1-F(c)$, which will henceforth be denoted $G(c)$. It should be noted that the probability of takeover does not depend on whether or not there is signaling. Again, this is because signaling does not change the fact that the raider's best guess of a stock's worth is just its current price.

We are now ready to construct the equilibria of the game. The equilibria that will be focused on here will be those that have the following properties: (1) they are Bayesian perfect equilibria: managers are required to be following the optimal action at date 1, given shareholder beliefs, and these beliefs are fulfilled by managers' actions along the equilibrium path; and (2) they satisfy the intuitive criterion of Kreps (1985); that is, they are characterized by "reasonable" beliefs off the equilibrium path.

With uninformed raiders, the model features what may be termed a discrete or "lumpy" signaling technology in the following sense: it will be impossible for a separating equilibrium to exist in which the good-state firm sells fewer than $x_{2}$ barrels in the first period. This is 
because (1) both types of firms have equal incentives to pass themselves off as good rather than bad or average; it raises both of their expected returns by the difference in stock price times the probability of takeover $G(c)$; and (2) both types of firms have the same marginal signaling cost below $x_{2}$. Hence if separation does occur, it will involve a cost of no less than $r x_{2} \cdot{ }^{7}$ The importance of lumpy separating costs is explained in the following proposition.

Proposition 1. Depending on parameter values, with uninformed raiders there can be both pooling and separating equilibria that are Bayesian perfect and robust to the intuitive criterion.

Thus this model differs from Spence's (1973) for which Kreps (1985) showed that there was a unique, separating Bayesian perfect equilibrium satisfying the intuitive criterion. Let us first see when a separating equilibrium can be supported in which managers always signal in the good state. In such an equilibrium, shareholders have separating beliefs so that their Bayesian updating process goes as follows: $(a)$ if they observe a profit of $x_{2}$, they are certain that they are in the good state ${ }^{8}$ and that the stock is worth $x_{1}(1+r)-r x_{2} ;(b)$ if they observe a zero profit, they are certain that they are in the bad state (since managers would have signaled had they been in the good state) and that the stock is worth $x_{2}(1+r)$.

What are the conditions under which it will be optimal for the managers to fulfill the shareholder beliefs by signaling in the good state? If management signals at date 1 , they will receive $x_{1}(1+r)$ - $r x_{2}$ with certainty: either a raider will take the firm over at that price or there will be no takeover, in which case the total date 1 and date 3 oil sales will yield that amount. If management does not signal, the stock price will be $x_{2}(1+r)$, and there is a probability $G(c)$ of a takeover at this low price. On the other hand, if there is no takeover, which occurs with probability $F(c)$, not signaling will have turned out to be a fortunate strategy, for total date 3 oil sales will net $x_{1}(1+r)$.

Putting these considerations together, we can see that, given separating beliefs, it will be optimal for managers to fulfill these beliefs by signaling in the good state when

$$
G(c)(1+r)\left(x_{1}-x_{2}\right)-r x_{2} \geq 0 .
$$

Inequality (2) implicitly defines the set of takeover costs $(c)$ for which a separating equilibrium can be supported. If we denote by $c_{s}$ the point at which (2) is met with equality, this set is simply all $c$ for

\footnotetext{
${ }^{7}$ This is in contrast to the "smooth" example in Spence's (1973) paper, in which the marginal cost of signaling is everywhere lower for the good type, so that with the right parameter values one can construct separating equilibria with arbitrarily small signaling costs.

${ }^{8}$ Actually, there is a trivial "openness" problem being ignored here: a profit of slightly more than $x_{2}$ is needed to establish that the firm is good.
} 
which $c \leq c_{s}$. In other words, if takeover costs are sufficiently low that the threat of takeover is high enough, there can be an equilibrium in which managers engage in the myopic signaling behavior.

Next, check the conditions under which there can be a pooling equilibrium. At first glance, it would appear that pooling equilibria should always involve zero oil sales at date 1 . Why should managers waste money when this expenditure does not help to distinguish their firm? However, it is in fact possible to construct pooling equilibria in which both types sell some small amount $x<x_{2}$ and that are not refined away by the intuitive criterion. ${ }^{9}$ As it turns out, consideration of these somewhat unnatural equilibria does not alter any of the conclusions to be sketched below. Thus for expositional simplicity, they are disregarded in what follows, and we will focus only on the more "reasonable" pooling equilibria in which date 1 oil sales are zero.

In a pooling equilibrium, shareholders have a different Bayesian updating process. When they observe a zero profit, they do not conclude that the firm is bad, but rather that there is only a $1-p$ probability of the firm's being bad since both good- and bad-state managers never show a date 1 profit. We also need to specify beliefs off the equilibrium path, that is, what shareholders would believe were they to observe $x_{2}$. In principle, these beliefs can be almost anything since $x_{2}$ is never observed, and hence Bayes's law need not apply. However, in order to construct pooling equilibria that satisfy the intuitive criterion, we must be more selective. It is straightforward to show that the only pooling equilibria that would survive the refinement process are those that have the following reasonable outof-equilibrium belief: "If $x_{2}$ is observed, the state must be good."10

Given pooling beliefs, managers do not have as strong an incentive to signal in the good state as they did under separating beliefs. Now, failure to signal depresses the stock price to only $(1+r)\left[p x_{1}+\right.$ $\left.(1-p) x_{2}\right]$ rather than to $x_{2}(1+r)$. As before, no signaling implies that there is a $G(c)$ probability of takeover at the low price and a probability $F(c)$ that there will be no takeover and revenues of $x_{1}(1+r)$. Signaling, on the other hand, would ensure a return of $x_{1}(1+r)-r x_{2}$. These considerations imply that it will be optimal for managers not to signal at date 1 if

$$
G(c)(1+r)(1-p)\left(x_{1}-x_{2}\right)-r x_{2} \leq 0 .
$$

\footnotetext{
${ }^{9}$ These equilibria are supported by the following out-of-equilibrium belief: "If I observe a firm with a profit of less than $x$, I will take it to be a bad firm with certainty."

${ }^{10}$ Imagine a pooling equilibrium in which a good firm would like to signal if it had to sell only $x_{2}$ but pools because out-of-equilibrium beliefs require much more to be sold to establish goodness. Such an equilibrium can be "broken" by the logic of Kreps since if a good firm actually did sell $x_{2}$, it would have to be judged good. A bad firm would never do so because it would find it prohibitively costly.
} 
If inequality ( 3 ) is met, then a pooling equilibrium can be sustained. This happens for all $c \geq c_{p}$, where $c_{p}$ is the threshold point at which (3) is met with equality. If takeover costs are high enough so that the probability of takeover is relatively small, there can be an equilibrium in which managers take the long-run view and always wait until date 3 to sell any oil. It bears repeating that such a pooling equilibrium is, by its construction, robust to refinement by the intuitive criterion.

It is clear from an inspection of (2) and (3) that $c_{p}<c_{s}$. This leads us to the following conclusions: (i) If $c$ is "low" (i.e., $c<c_{p}$ ), then the unique equilibrium of the game involves myopic signaling by managers. (ii) If $c$ is "high" (i.e., $c>c_{s}$ ), then the unique equilibrium of the game is one with no signaling. (iii) If $c$ is "intermediate" (i.e., $c_{p} \leq c$ $\leq c_{s}$ ), there can be two pure strategy equilibria. Separating beliefs on the part of shareholders can lead to separating behavior on the part of managers, and pooling beliefs can lead to pooling behavior.

Before we proceed any further, it should also be noted that mixed strategy equilibria exist in the intermediate cost range. In a mixed strategy equilibrium, the manager sometimes signals in the good state and sometimes does not. Consequently, a shareholder observing zero profit attributes a probability $\alpha$ to the possibility that the state is good, with $\alpha<p$. With beliefs given by such an $\alpha$, managers will be indifferent between signaling and not signaling (and hence be willing to pursue a mixed strategy) if

$$
G(c)(1+r)(1-\alpha)\left(x_{1}-x_{2}\right)-r x_{2}=0 .
$$

Equation (4) tells us that for each $c$ in the intermediate range, there exists a unique randomizing scheme (parameterized by $\alpha$ ) over the pure strategies (signal, do not signal) that supports a mixed strategy equilibrium. For the remainder of this paper, however, these mixed strategy equilibria will be accorded little attention. The primary emphasis will be on the pure strategy equilibria.

Looking at these equilibria, we can come to unambiguous conclusions when $c$ is in the high or low range. However, when $c$ is in the intermediate range, it is not clear what the outcome will be. If shareholders have pooling beliefs, there will be pooling. If they have separating beliefs, there will be separation. There seems to be no a priori reason why one equilibrium should be more likely than the other. ${ }^{11}$

${ }^{11}$ It should be noted that both types of equilibria are stable in the following sense: Given separating beliefs on the part of all other shareholders, a long deviating shareholder will not do better if he has pooling beliefs and tries to buy shares in companies that others judge poorly. (If he has to pay even a tiny bit more than the market price for such shares, he will do strictly worse.) Conversely, a lone deviator to separating beliefs will not do better if everyone else has pooling beliefs. 
An interesting interpretation of the multiple equilibrium situation is that, for a range of $c$ 's, the detrimental effect of a given amount of takeover pressure depends on how patient stockholders are. If stockholders have pooling beliefs, they do not think too badly of a company that shows temporarily low profits. They realize that it may be a good company following a long-run strategy that calls for heavy investment today. Given such beliefs on the part of stockholders, the company is indeed free to pursue long-run policies because such policies do not hurt the stock price greatly and hence do not cause an unacceptable expected loss in the face of takeover pressure.

If, however, stockholders have separating beliefs, they judge a company very harshly if it does not produce a current profit. They take it to be a bad company with certainty. With such beliefs, companies are forced into behaving myopically because failing to produce a profit causes an undervaluation that is unacceptably large given the level of takeover pressure.

The idea that managerial myopia may depend on the attitudes of shareholders is often expressed by members of the business community and the press. For example, Greenhouse (1986) places some of the blame for increased shortsightedness by management on the growing percentage of stock held by "pension fund managers and other institutional investors [who are] generally more fickle than individual investors ... and [who can] dump a stock literally moments after bad quarterly news is issued" (sec. 3, pp. 1, 8).

The model of this paper can go only so far in rationalizing this quote because it does not specify a mechanism by which one of the equilibria is selected in the intermediate range. One cannot rigorously claim that there are exogenous differences between pension fund managers and individual investors that make the preferred pooling equilibrium more likely with the latter. One can say, in the context of the model, only that they have been lucky in getting stuck in this equilibrium.

Even though the model fails to predict from exogenous considerations when shareholders will have pooling or separating beliefs in the intermediate cost range, it is still useful to distinguish the two possibilities in the following way: We will say that stockholders are "patient" if, when there is a choice, the pooling equilibrium is observed. Thus with patient stockholders, separating equilibria occur only when costs are low-when $c<c_{p}$. Analogously, stockholders are "impatient" if, when there is a choice, the separating equilibrium is observed. With impatient stockholders, separating equilibria are easier to get: it is necessary only that $c \leq c_{s}$. Hence patient stockholders lead to higher levels of social welfare when costs are in the intermediate range.

When raiders are uninformed, we can draw the following general conclusions for social welfare. 
Proposition 2. With uninformed raiders, $(a)$ welfare is not monotonic in $c$, and $(b)$ takeovers can lead to ex ante welfare losses, whether shareholders are patient or not.

As we lower the cost of takeovers $c$, we eventually hit a threshold (at $c_{p}$ for patient stockholders, at $c_{s}$ for impatient stockholders) at which managers begin to behave myopically. This entails a discrete drop in ex ante social welfare in the amount prx $x_{2}$ - the probability of signaling times the resources wasted in signaling.

This discrete drop in welfare can evidently be quite large because it can lead to ex ante welfare losses. As an example of part $b$ of the proposition, suppose that $c=0$ and that $v$ is nonstochastic and greater than zero. In this case, the probability of a takeover is one, and signaling will be assured (even with patient stockholders) if $(1-p)(1+r)\left(x_{1}-x_{2}\right)-r x_{2}>0$. The expected synergy gains from takeovers are $v$, and the expected costs of signaling are prx $_{2}$. Clearly, it is possible to have a case in which both $v-p r x_{2}<0$ and the signaling condition above is met. In such a case, a world in which takeover costs are infinite is preferable to one in which they are zero.

\section{The Case of Informed Raiders}

Let us now turn to the case in which raiders share the managers' inside information about which state of the world prevails at time 1 . In this case, the results about lumpy costs of separation and pooling equilibria disappear (along with any distinctions between patient and impatient shareholders).

Proposition 3. There can be separating equilibria in which arbitrarily small signaling costs (less than $r x_{2}$ ) are incurred by the good firm.

Proposition 4. Pooling equilibria robust to the intuitive criterion no longer exist unless the cost of takeovers is so high that a good firm faces a zero probability of takeover in a pooling equilibrium.

The propositions (which are formally verified in the Appendix) may appear surprising given that the cost of signaling is still the same for both types of firms below $x_{2}$. However, it must be recognized that the benefit of a high stock price is now greater for good firms than for bad firms because, with informed raiders, a good firm that has a high stock price has a greater probability of being taken over than a bad firm with a high stock price. Informed raiders are relatively unlikely to pursue a target that they know to be overpriced.

With the elimination of the pooling equilibria, the model now always has a unique separating equilibrium that satisfies the intuitive criterion. The signaling costs incurred by the good firm in this equilibrium are straightforward to calculate. In equilibrium, the bad firm 
earns a return of $(1+r) x_{2}$. If it had a high stock price (corresponding to being judged a good firm), its expected return would be given by

$$
(1+r)\left[x_{2}+G(z)\left(x_{1}-x_{2}\right)\right],
$$

where $z$ is defined as $z=c+(1+r)\left(x_{1}-x_{2}\right)$. Note that the probability that a bad firm with a high stock price will be taken over, $G(z)$, reflects the amount that the raider must overpay for the firm. The amount a bad firm would gain from boosting its stock price to the value of the good firm is simply $(1+r) G(z)\left(x_{1}-x_{2}\right)$. For the equilibrium to remain separating, the cost of signaling must exceed this value so that the bad firm has no desire to masquerade as the good firm. For the equilibrium to satisfy the intuitive criterion, the cost of signaling must be the minimum amount that accomplishes this separation. Fudging the trivial openness problem leads to the claim that the equilibrium signaling costs are given by

$$
r x^{*}=\min \left\{r x_{2},(1+r) G(z)\left(x_{1}-x_{2}\right)\right\} .
$$

This equation leads directly to the following result.

Proposition 5. When raiders are informed, the takeover mechanism can never lead to ex ante welfare losses. Even though welfare may not be monotonic in $c$, it is guaranteed that any finite $c$ is preferable to an infinite $c$.

The proposition is proved in the Appendix. The intuitive justification is straightforward. Ex ante welfare reduction requires that the improvement $v$ be, "on average," small relative to the signaling costs. But if $v$ is usually small, signaling costs as given by (6) will be small too with an informed raider. A bad firm will not have much incentive to raise its stock price because the probability of its being taken over at an inflated price is low. Consequently, good firms do not have to spend a great deal to credibly separate themselves.

If we compare the results with informed raiders with those with uninformed raiders, we see that uninformed raiders are preferable over the cost region in which they lead to pooling outcomes since informed raiders always entail some signaling cost. Over the cost region in which both types of raiders lead to separating outcomes, equation (6) tells us that informed raiders are preferred. ${ }^{12}$

12 This preference for informed raiders is increased if we consider a perturbation of the model that eliminates the pooling outcomes in the uninformed raider case. Suppose we change the cost structure slightly so that the marginal cost of signaling for the bad firm is raised infinitesimally to $r+\epsilon$ while that for the good firm is left at $r$. It is easy to show that with uninformed raiders we are left with a single separating equilibrium that satisfies the intuitive criterion, and that signaling costs are approximately equal to $\min \left\{r x_{2},(1+r) G(c)\left(x_{1}-x_{2}\right)\right\}$. The results for the informed raider case are, on the other hand, approximately unchanged from eq. (6): both cases now feature signaling costs that increase smoothly with decreases in $c$, up to a limit of $r x_{2}$. And over the range of increase, uninformed raiders always lead to the higher costs. 
These relatively optimistic results for informed raiders may appear somewhat counterintuitive: one might have expected them to cause more problems than their uninformed counterparts. As it turns out, the results are strongly dependent on the assumption that manager and shareholder interests coincide. When this assumption is removed, the conclusions can be reversed.

Suppose that, in addition to their return from the stock, managers also derive some further benefit from retaining control of the firm. ${ }^{13}$ We might write their utility function as $U=Y+\beta C$, where $Y$ is the total proceeds from ownership of the firm's stock and $C$ is an indicator variable that takes on the value one when managers retain control and the value zero when there is a raid that ousts management. The parameter $\beta$ is a measure of how strong the desire for control is. ${ }^{14}$

In order to maximize expected utility, managers who value control will wish to take measures to lessen the probability of takeover. With uninformed raiders, this has no effect since, as we have seen, managerial signaling does not change the probability of takeover when raiders are uninformed.

However, when raiders are informed, control-oriented managers of bad firms will have increased incentive to pass their firm off to shareholders as being good since, by raising the price above what the raider knows is the fair value, they can lower the probability of a raid. Similarly, managers of good-state firms who value control will be less willing to let their firms be unfavorably judged in the marketplace. Thus with informed raiders, managerial taste for control forces signaling costs up. In the polar case of $\beta=\infty$, when managers care only about control at the expense of the stockholders, good-state managers will always pay the full signaling cost of $r x_{2}$ for any level of $c$ that entails $G(c)>0$.

This sort of logic implies that if managers value control sufficiently, the conclusions above are reversed: informed raiders become more problematic than uninformed ones, and any presumption that informed raiders can prevent the takeover mechanism from causing ex ante welfare losses must be abandoned. In this model, the takeover mechanism can exacerbate managerial moral hazard problems: instead of making slacking managers work harder, it may lead them to further waste the firm's resources in an effort to remain entrenched.

\section{Implications of the Model}

This is certainly not the first formal model to suggest that the reactions of managers to takeover pressure can have undesirable effects,

\footnotetext{
${ }^{13}$ Perhaps it would be costly for them to search for new jobs that offer the same compensation and status as their current ones.

${ }^{14}$ Baron (1983) employed a similar formulation.
} 
even in the absence of managerial moral hazard. Baron (1983) analyzed a model in which managers can refuse a takeover bid by a raider when it is made. He found that even if the decision to refuse a bid is in stockholder interests at the time it is made, the freedom to make such a decision can lead to ex ante welfare losses. In other words, stockholders might be better off if managers could be bound to never refusing bids. ${ }^{15}$ Shleifer and Vishny (1986) suggested similar conclusions regarding the paying of "greenmail" by target firms to potential raiders. Although they modeled greenmail as part of a subgame perfect strategy of managers who act in the interests of shareholders, they noted that it is nonetheless possible that outlawing greenmail would lead to ex ante improvements in shareholder welfare.

These arguments lend credence to the beliefs of people such as Easterbrook and Fischel (1981) who advocate "managerial passivity" rules that would prevent managers from reacting to takeover bids. In the view of these writers, the ability of management to interfere in the takeover process detracts from the basic virtues that takeovers confer onto society. Their prescription is a simple one: ban managerial activism and give the takeover mechanism as free a reign as possible.

The managerial myopia problem analyzed here is structurally very similar to the bid refusal and greenmail problems mentioned above. Even when managers act in shareholders' interests, the perfect equilibrium is ex ante inferior to what could be achieved if managers could be bound to never signaling. However, the policy implications of managerial myopia are very different. Bid refusal, greenmail, and other defensive maneuvers that are undertaken at the time of a takeover bid are usually highly visible. Outlawing such forms of managerial resistance is a viable option since they are easily detected and documented.

Managerial myopia, by contrast, is relatively invisible. It may take place behind the scenes in vast numbers of firms that are never subject to a takeover bid; it may be very difficult to observe cleanly and even tougher to document in court. It is a consequence of two inevitable facts: that managers will tend to be better informed about the prospects of their firms and that they will have to be given some discretion in decision making.

If managerial myopia is indeed a problem of serious magnitude and it cannot be simply banned, then some control of the takeover mechanism may be a second-best alternative. If this is not undertaken at the regulatory level, companies may wish to do it themselves by

${ }^{15}$ This is due to adverse selection. If raiders are uninformed, they will be less likely to bid for targets in which the management can refuse the bid. They fear that the only bids that will be accepted will be those for which the target management knows that they have overbid. 
enacting antitakeover amendments in their corporate chartersexactly the sort of managerial activism that Easterbrook and Fischel oppose. While empowering managers to block takeovers might be undesirable in a world with no myopia (i.e., when the Baron analysis applies), this is no longer true when the forces described in this paper are present.

What evidence is there concerning the managerial myopia hypothesis? A great deal of the empirical literature on takeovers has implicitly ignored the very possibility of its existence by $(a)$ only focusing on the stocks of companies directly involved in takeover bids and (b) using the maintained assumption that the market price always reflects the full information value of the firm; that is, that there are no informational asymmetries among managers, raiders, and shareholders. A typical approach is to perform an event study and note that the stock of a target appreciates strongly with a bid, while that of the acquirer tends to change less significantly. The conclusion then drawn is that the takeover mechanism must be creating new value and that target firms wind up capturing most of the surplus generated. ${ }^{16}$

Such a conclusion is erroneous on two counts. First, whether takeover pressure makes managers work harder or makes them behave more myopically, it must be true that a lot of the action, for better or for worse, occurs rather invisibly in companies that are never actually subject to bids. Second, taking market prices to reflect full information values almost amounts to assuming the synergy hypothesis. Of course, target prices appreciate with a bid. But this does not necessarily imply that the target becomes more valuable. It is also possible that it was underpriced before the bid and has simply come closer to being priced correctly. The managerial myopia hypothesis presumes that such deviations in prices from their complete information values play a role in takeover activity. This presumption is consistent with the findings of Bradley (1980), who observed that, after unsuccessful bids, the stocks of target firms tend to retain much of the price appreciation that they realize during the course of takeover attempts. By the very act of making a takeover bid, a raider seems to communicate some positive new information concerning the value of its target.

Other empirical evidence has sometimes been used to argue directly against the managerial myopia hypothesis. However, on closer examination, this evidence often appears ambiguous in its implications. For instance, a study by the Office of the Chief Economist of the Securities and Exchange Commission (1985) found that firms with low R \& D expenditures are not taken over less frequently than those

${ }^{16}$ See Jensen and Ruback (1983) for references to this literature. 
with higher R \& D spending. On the surface, this seems to indicate that myopic behavior does not prevent raids. But such a conclusion ignores a significant sample selection problem: as the model of this paper suggests, low R \& D should be observed in those firms for which the ex ante probability of takeover is the highest. Thus even if this myopia is deterring some raids, more raids may still be observed among myopic firms than among nonmyopic ones, which face a lower ex ante probability of takeover.

Also cited in the myopia debate are the findings of McConnell and Muscarella (1985), who observed that stock prices (except in the oil industry) respond positively to announcements of increased investment expenditures. Jensen (1986, p. 11), extolling the virtues of the takeover mechanism, noted that this observation is "inconsistent with the notion that the equity market is myopic." While this is correct, it misses the point. The McConnell-Muscarella observation is consistent with the notion that managers are myopic: the more reluctant managers are to invest, the higher will be the present value of those few projects that they do find sufficiently attractive to undertake and, hence, the more positive should be the market reaction to the announcement of a new investment. ${ }^{17}$

On the other side of the argument, an interesting empirical point has been raised by Linn and McConnell (1983). They studied the reaction of stock prices to the adoption of antitakeover charter amendments, such as supermajority provisions, which give management much greater power to block undesired takeovers. As noted earlier, the model of this paper implies that such amendments should improve the value of the firm as long as manager and shareholder interests coincide. Managers need not waste resources to deter unfairly low bids if they can simply turn them down. And indeed, Linn and McConnell found that share prices respond positively to the passage of antitakeover provisions.

Of course, these results are also subject to more than one interpretation and do not "prove" the existence of managerial myopia. Linn and McConnell noted that they are also consistent with shareholders who believe that antitakeover provisions put management in a better position to bargain with raiders on their behalf. ${ }^{18} \mathrm{~A}$ third possibility is that there is asymmetric information, and the adoption of the provi-

${ }^{17}$ Jensen himself made this distinction between myopic managers and myopic stock prices. However, his arguments suggest that what he thinks is relevant to the takeover debate is the latter, not the former.

${ }^{18}$ Actually, stockholder perceptions may not always be correct in this case. As Baron pointed out, the freedom to bargain with raiders, while ex post desirable for good firms, could lead to ex ante expected losses if raiders are uninformed and can be adversely selected against. The raiders will be reluctant to attempt takeovers and there will be less synergistic surplus available. 
sions causes the market to revise upward the probability it attaches to a possible takeover attempt. While this evidence is thus somewhat ambiguous in its support of the managerial myopia hypothesis, it seems no less so than that used to argue against it. ${ }^{19}$ Furthermore, no matter how they are interpreted, the Linn-McConnell findings cast doubts on the claims of Easterbrook and Fischel and others whose arguments implicitly rely on symmetric information and who conclude that no interference with the takeover mechanism should be tolerated.

\section{Appendix}

\section{Proof of Proposition 3}

This can be demonstrated by an example. Let $c=0$ and $v$ be nonstochastic and less than $(1+r)\left(x_{1}-x_{2}\right)$. Consider a situation in which the good firm separates by selling a very small amount of oil, at a total cost of $\epsilon$.

This situation is an equilibrium: the bad firm would not wish to spend $\epsilon$ to be judged good by the market because the probability of takeover by an informed raider of an overpriced firm is zero (since the improvement $v$ is less than the excess over fair value a raider has to pay to acquire a bad firm at a good-firm price). On the other hand, the good firm is willing to pay $\epsilon$ to be judged good since it faces a takeover probability of one.

\section{Proof of Proposition 4}

Suppose that a pooling equilibrium did exist. In such an equilibrium, a raider can take either type of firm over for a price $P$ such that

$$
(1+r)\left[p x_{1}+(1-p) x_{2}\right]<P<(1+r) x_{1} .
$$

That is, a raider has to pay more than the ex ante expected value of the firm because a takeover bid by an informed raider communicates some information to previously uninformed shareholders, causing them to revise upward their valuation (see Grossman and Hart 1981).

The probability that a good firm gets taken over in a pooling equilibrium is thus $G\left(z_{1}\right)$, where $z_{1}=c+P-(1+r) x_{1}$. The probability that a bad firm gets taken over is $G\left(z_{2}\right)$, where $z_{2}=c+P-(1+r) x_{2}$. If a good firm could separate itself as good, it would thus gain an expected amount $G\left(z_{1}\right)\left[(1+r) x_{1}\right.$ $-P]$ over what it earns in the pooling equilibrium. If a bad firm could be judged good, it would gain an expected amount $\left[G(z)(1+r)\left(x_{1}-x_{2}\right)\right]$ $-\left\{G\left(z_{2}\right)\left[P-(1+r) x_{2}\right]\right\}$ over what it earns in pooling. (Recall that $z$ is defined as $z=c+[1+r]\left[x_{1}-x_{2}\right]$.) It is straightforward to verify that the good firm's gain always exceeds the bad firm's. Thus the intuitive criterion rules out such a pooling equilibrium.

${ }^{19}$ A sharper test might be to examine a measure of managerial farsightedness such as capital or R \& D expenditures before and after the adoption of antitakeover provisions. 
Proof of Proposition 5

The ex ante gains due to the takeover mechanism are given by

$$
G(c) E(v-c / v \geq c)-p r x^{*} .
$$

It follows directly from the properties of conditional expectation and the fact that $z>c$ that (A2) is greater than or equal to

$$
G(z) E(v-c / v \geq z)-p r x^{*} .
$$

Since $E(v-c / v \geq z) \geq z-c=(1+r)\left(x_{1}-x_{2}\right)$, it must be that (A3) is greater than or equal to

$$
G(z)(1+r)\left(x_{1}-x_{2}\right)-p r x^{*} .
$$

Given the value of $r x^{*}$ in equation (6) of the text, it is now clear that (A4) is positive. Thus the ex ante gains due to the takeover mechanism can never be less than zero when raiders are informed.

\section{References}

Auletta, Ken. Greed and Glory on Wall Street: The Fall of the House of Lehman. New York: Random House, 1986.

Baron, David P. "Tender Offers and Management Resistance." J. Finance 38 (May 1983): 331-43.

Bhattacharya, Sudipto. "Imperfect Information, Dividend Policy, and 'the Bird in the Hand' Fallacy." Bell J. Econ. 10 (Spring 1979): 259-70.

Bradley, Michael. "Interfirm Tender Offers and the Market for Corporate Control." J. Bus. 53 (October 1980): 345-76.

Diamond, Douglas W., and Dybvig, Philip H. "Bank Runs, Deposit Insurance, and Liquidity." J.P.E. 91 (June 1983): 401-19.

Easterbrook, Frank, and Fischel, Daniel. "The Proper Role of a Target's Management in Responding to a Tender Offer." Harvard Law Rev. 94 (April 1981): 1161-1204.

Greenhouse, Steven. "The Folly of Inflating Quarterly Profits." New York Times (March 2, 1986).

Grossman, Sanford J., and Hart, Oliver D. "Takeover Bids, the Free-Rider Problem, and the Theory of the Corporation." Bell J. Econ. 11 (Spring 1980): 42-64.

- "The Allocational Role of Takeover Bids in Situations of Asymmetric Information." J. Finance 36 (May 1981): 253-70.

Jensen, Michael C. "The Takeover Controversy: Analysis and Evidence." Midland Corp. Finance J. 4 (Summer 1986): 6-32.

Jensen, Michael C., and Ruback, Richard S. "The Market for Corporate Control: The Scientific Evidence." J. Financial Econ. 11 (April 1983): 5-50.

Kreps, David M. "Signalling Games and Stable Equilibria." Mimeographed. Stanford, Calif.: Stanford Univ., 1985.

Kuttner, Robert. "The Truth about Corporate Raiders." New Republic 194 (January 20, 1986): 14-19.

Linn, Scott C., and McConnell, John J. "An Empirical Investigation of the Impact of 'Antitakeover' Amendments on Common Stock Prices." J. Financial Econ. 11 (April 1983): 361-99.

McConnell, John J., and Muscarella, Chris J. "Corporate Capital Expenditure Decisions and the Market Value of the Firm." J. Financial Econ. 14 (September 1985): 399-422. 
Scharfstein, David. "The Disciplinary Role of Takeovers." Mimeographed. Cambridge: Massachusetts Inst. Tech., 1985.

Securities and Exchange Commission, Office of the Chief Economist. "Institutional Ownership, Tender Offers, and Long-Term Investments." Mimeographed. Washington: Securities and Exchange Comm., 1985.

Shleifer, Andrei, and Vishny, Robert W. "Greenmail, White Knights, and Shareholders' Interest." Rand J. Econ. 17 (Autumn 1986): 293-309.

Spence, A. Michael. "Job Market Signaling." Q.J.E. 87 (August 1973): 35574. 